DOI: $10.2478 / \mathrm{v} 10190-010-0001-7$

\title{
EFFECTS OF CLIMATE CHANGE ON MICROBIAL COMMUNITY STRUCTURE AND FUNCTION IN THE ANTARCTIC GLACIER LAGOON
}

\author{
ALEKSANDER ŚWIĄTECKI*, DOROTA GÓRNIAK*, \\ KATARZYNA JANKOWSKA ${ }^{* *}$, MAREK K. ZDANOWSKI ${ }^{* * *}$, \\ PIOTR BORSUK ${ }^{* * * *}$, MAGDALENA J. ŻMUDA-BARANOWSKA ${ }^{* * *}$$$
\text { JAKUB GRZESIAK }{ }^{* * *}
$$ \\ "Department of Microbiology, University of Warmia and Mazury, Oczapowskiego 1A, \\ 10-719 Olsztyn, Poland, aswiat@uwm.edu.pl, \\ ** Department of Water and Wastewater Technology, Technical University of Gdańsk, \\ Poland, \\ *** Department of Antarctic Biology, Polish Academy of Sciences, Warsaw, Poland, \\ **** Institute of Genetics and Biotechnology, Warsaw University and Institute of Bio- \\ chemistry and Biophysics Polish Academy of Sciences
}

\begin{abstract}
One of the dramatic effects of global warming is the retreat of glaciers. This phenomenon has intensified in the last two decades. Postglacial areas are quickly colonised by various groups of organisms. Auto- and heterotrophic microorganisms play an especially vital role in these processes. They thrive in shallow glacial lagoons which often form in front of retreating glaciers. These reservoirs are characterised by high dynamics of physicochemical parameters, including: salinity, temperature and concentrations of organic compounds and nutrients. The conducted microbiological studies have revealed rich structural and functional diversity of bacteria occurring in the ecosystem of Ecology Lagoon situated on King George Island. Bacteria found on the surface of algae and stones in the shore zone of the lagoon showed particularly intense metabolic activity. A molecular analysis has indicated that unique taxonomic groups of bacteria occur in the ecosystem of Ecology Lagoon.
\end{abstract}

KEY WORDS: climate change, microbial community, glaciers recession, glacier lagoons. 


\section{INTRODUCTION}

Glaciers are the largest freshwater reservoir in the hydrosphere. They are found in many areas around the globe. Most of them are located in the polar zones, predominantly in the form of continental ice sheets. These are mainly glaciers of Antarctica, which represent about $90 \%$ of all glacier ice on Earth. The retreat of glaciers in the Antarctic is a fact well-documented in scientific literature (Rignot 1998). At present, changes in the structure and scope of glaciers are a good indicator of global climate change. Scientists' attention, especially during the last International Polar Year (2007-2008), was focused on various issues of global warming and its consequences in the form of continental ice sheet melting (Anisimov and Belolutskaia 2004,Dickson 2009). Deglaciation processes create new areas colonised mainly by autotrophic and heterotrophic microorganisms (Zdanowski et al. 2004, 2005, Grzesiak et al. 2009). The fundamental aim of the conducted studies was to determine the structural and functional characteristics of the microbiocenoses which occur in the lagoon formed in front of a retreating glacier. This paper presents preliminary results of microbiological studies carried out in 2008-2010 within the framework of the project CliCoPen (ID-34): Impact of Climate induced glacial melting on marine and terrestrial Coastal communities on a gradient along Western Antarctic Peninsula. The studies were conducted as part of the $33^{\text {rd }}$ Antarctic Expedition in the Polish H. Arctowski Antarctic Station, King George Island, Antarctica (Fig. 1).

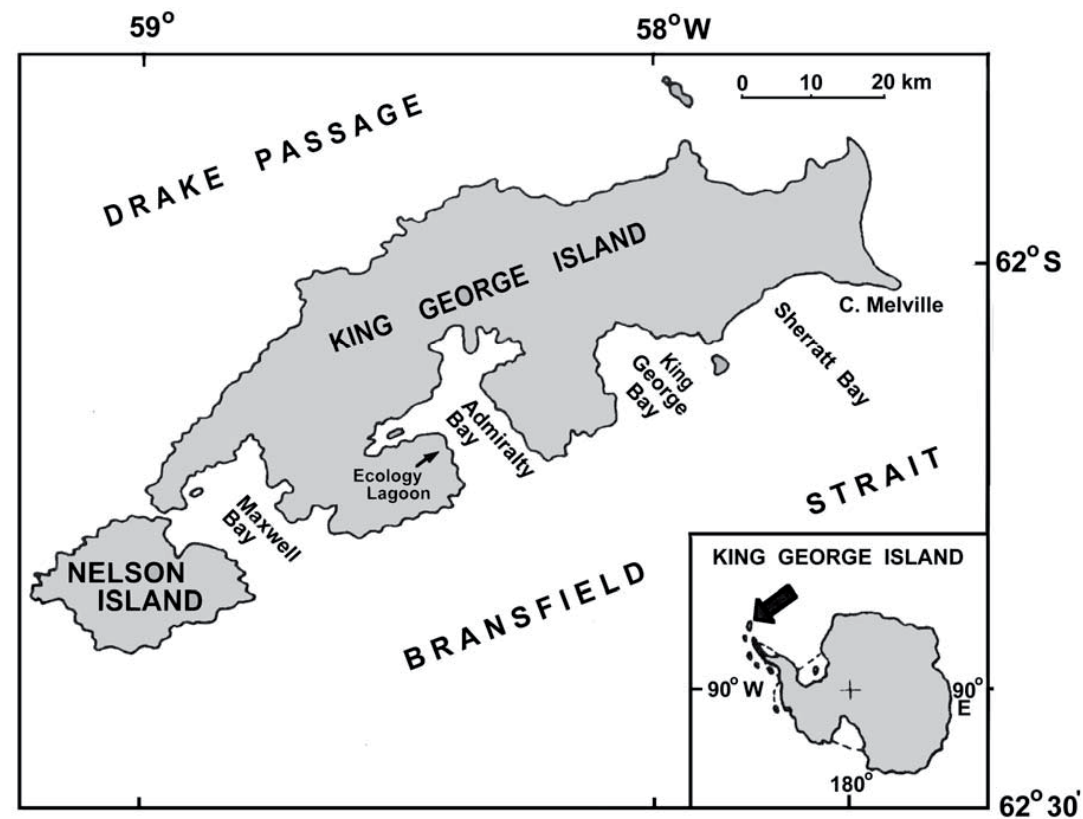

Figure 1. Location of Ecology Lagoon on King George Island (box) and in Antarctica (according to Birkenmajer 2002) 


\section{CHARACTERISTICS OF THE ECOLOGY LAGOON}

Located in the northern part of the Antarctic Peninsula, King George Island is particularly vulnerable to climate change and represents a hot spot of global warming processes. Increased melting and retreat of glaciers have also been noted in the Polish Antarctic Station. In a relatively short time, from 1989 to 2001, the ice front of the Ecology Glacier retreated about $400 \mathrm{~m}$, and a shallow semi-enclosed bay formed at its foreland (Birkenmajer 2002). Ecology Lagoon has an area of 16.1 ha, and at low tide the bay is maximum $2.4 \mathrm{~m}$ deep. Two spits partly separate the reservoir and limit water mixing between the ocean and the lagoon especially at low tides (Fig. 2). Ecology Lagoon was characterised by considerable daily variability of physico-chemical and biological parameters determined mainly by ocean tides. High dynamics of water salinity was an especially significant factor affecting the biocenosis of Ecology Lagoon (Fig. 3). The highest and very uniform level of salinity of the lagoon waters was observed at high tide. Greater salinity in the bottom layer of the water body was a characteristic phenomenon. The surface waters

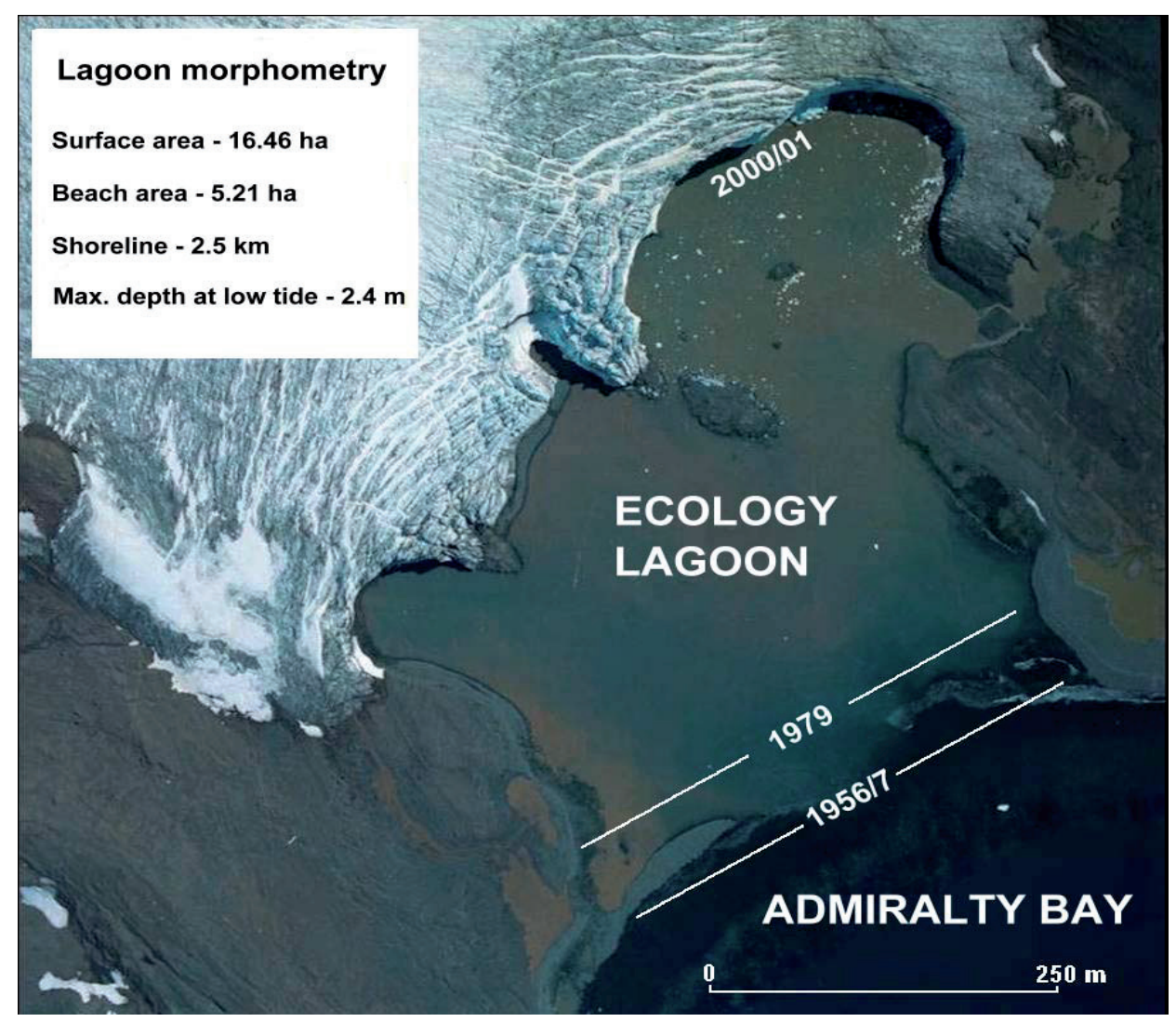

Figure 2. Ecology Lagoon, glacier front position (1956/7, 1979, 2000/01) 
were less saline. At low tide, high spatial differentiation of salinity was observed. The lowest values were recorded in the zones of intensive inflow of glacier waters. A cyclic decrease of water salinity led to a significant increase in the mortality of halophiles. Experimental studies carried out by Janecki et al. (2010) showed great vulnerability of ocean organisms to water salinity decline. Organic matter carried from the ocean to the shores of Admiralty Bay was the subject of detailed analyses. With wet weight of about 74000 tonnes, macroalgae cover $30 \%$ of the bay bottom and play a particularly vital role in the organic matter supply to the shores (Zieliński 1990, Rakusa-Suszczewski 1995). It was estimated that about $100 \mathrm{~kg}$ of dry algal weight is deposited annually per $1 \mathrm{~m}^{2}$ of the beach. Algae are a source of organic matter, nutrients and some important microelements (Rakusa-Suszczewski and Zieliński 1993). Intensive physical, chemical and microbiological decomposition of algal biomass fertilizes Antarctic soils, inland water bodies and lagoons. Experimental studies conducted by Nędzarek and Rakusa-Suszczewski (2004) showed that $80 \%$ of the nutrients from the total algal biomass were released in the first 3 days after its deposition on the shore. In the course of our study we found that a similar mechanism of organic matter and nutrient supply occurs in the Ecology Lagoon area. An analysis of dissolved organic carbon (DOC) indicated its varied concentrations in the water body (Fig. 4). At high tide, higher concentrations of

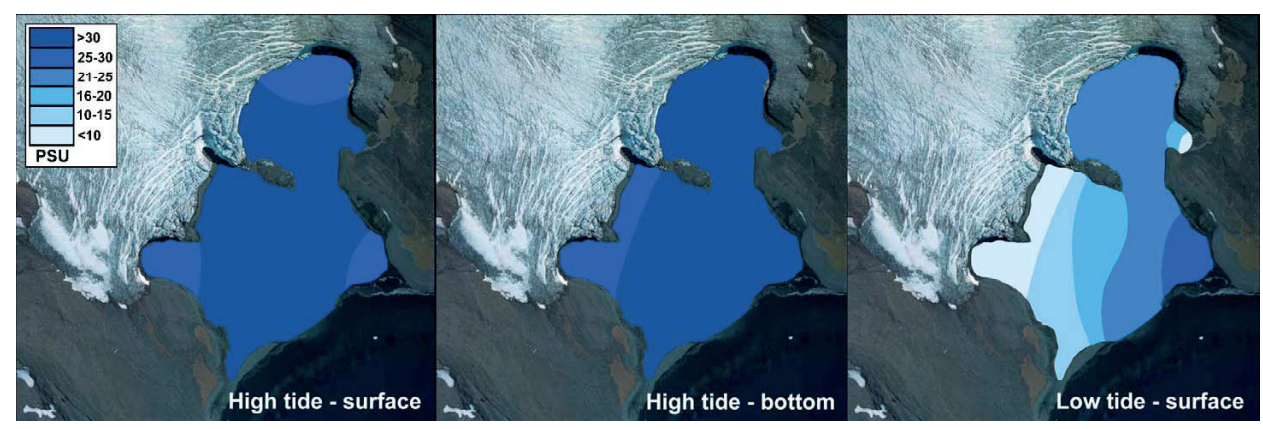

Figure 3. Water salinity (PSU) dynamics in Ecology Lagoon (summer 2008/09)

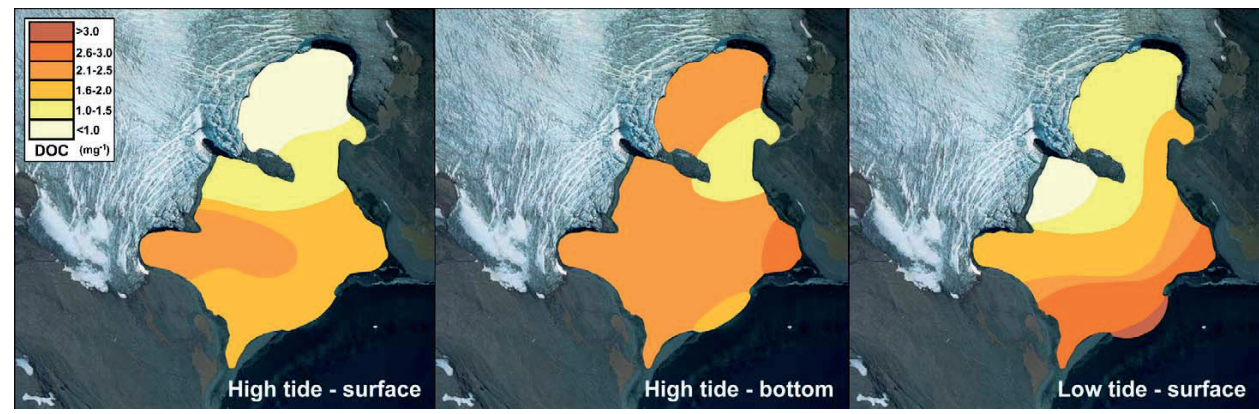

Figure 4. Dissolved organic carbon (DOC) dynamics in Ecology Lagoon (summer 2008/09) 
DOC were observed in the bottom layer. In the surface water layer, a higher concentration of DOC was recorded only in the area of water inflow from the glacier. At low tide, DOC concentrations gradually increased from the glacier front to the lagoon mouth. This phenomenon may be of considerable importance in the local water enrichment of the Admiralty Bay waters.

\section{MICROBIOLOGICAL STUDIES}

The studies on the bacteriocenosis of Ecology Lagoon were carried out using classic and molecular analytic techniques. Several transects, where water and bottom sediment samples as well as material from the surface of stones and algae were collected, were established in the lagoon area. The abundance and mean volume of bacteria were determined by microscopic analyses (DAPI staining). The viability and physiological activity of the microorganisms were analysed by means of staining performed using special biochemical probes (Boulos et al. 1999, Bartosch et al. 2003) The taxonomic structure of the bacteriocenosis was analysed by amplification of specific fragments of $16 \mathrm{~S}$ rRNA genes. A combination of the PCR reaction and denaturating gradient gel electrophoresis (DGGE) was used (Muyzer et al. 1993). This method enables identification of dominating DNA sequences corresponding with particular bacteria species occurring in the material under study.

The microbiological studies of the Ecology Lagoon water showed high daily and spatial dynamics of individual parameters. The abundance of bacteria ranged from $2.4 \times 10^{5}$ to $2.2 \times 10^{6}$ cells in $1 \mathrm{ml}$. The lowest values were recorded in the areas of water inflow from the glacier. A statistically significantly greater abundance of bacteria was found in bottom waters and littoral zones. A substantial amount of mineral suspension was a characteristic feature of the lagoon waters at low tide. Numerous bacteria were attached to the particles of the mineral seston. The number of aggregated bacteria reached $30 \%$ of the total number of bacteria. The volume of bacteria occurring in the lagoon waters ranged from 0.04 to $0.15 \mu \mathrm{m}^{3}\left(0.12 \mu \mathrm{m}^{3}\right.$ on average) and was slightly larger than the values recorded for ocean bacteria. Based on biochemical markers, an analysis of viability and metabolic activity of bacteria found in the lagoon waters indicated values typical of bacteria occurring in aquatic environments (Junge et al. 2004). Bacteria with an active, viable cytoplasmatic membrane represented $16 \%$ of the total number on average. Only $6 \%$ of the bacteria indicated an active electron transport system (ETS + ). Bacteria aggregated and attached to the surface of the amorphous mineral seston were characterised by the highest metabolic activity. The analysis of the microorganisms found on the surface of stones and macroalgae showed that the bacteriocenosis was different in structure and physiology. The microorganisms obtained from these samples were much larger, with a maximum length of $15 \mu \mathrm{m}$ (Fig. 5). The bacteria on the surface of stones were characterised by the formation of sheaths. The release of extra- 


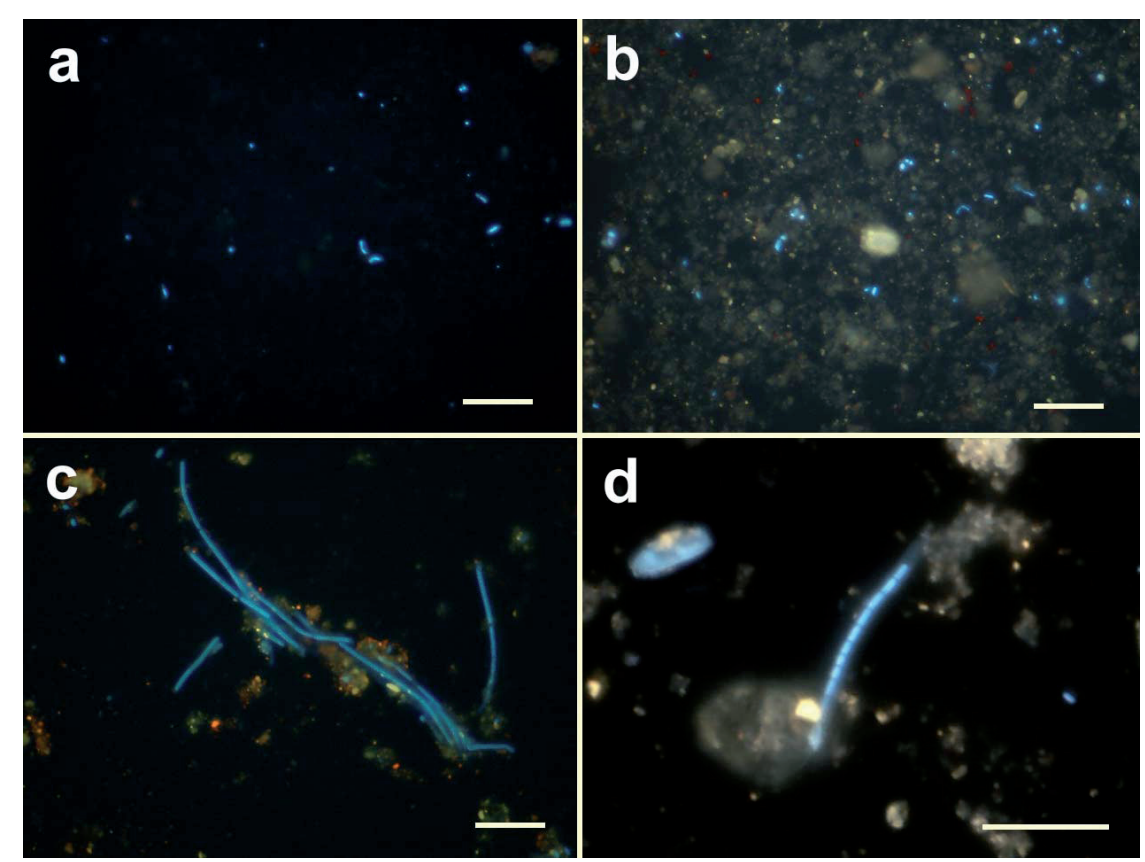

Figure 5. Bacterial structure in selected habitats: a) ocean water, b) lagoon water, c) stone surface, d) bacterial sheath, bar- $10 \mu \mathrm{m}$

cellular polymeric substances (EPS) is typical of sessile microorganisms. These substances can perform important functions in the immobilisation and protection of cells (Poli 2010). EPS release belongs to mechanisms which allow survival under environmental stress conditions. This stress may result from the lack of basic nutrients or unfavourable factors such as low temperature or rapid changes in osmotic conditions (Nyström 1995, López et al. 1998). In both cases the defensive mechanism consists in the synthesis of specific polymers which produce a matrix enabling the formation of microorganism aggregates, such as biofilm for example. From the chemical point of view, extracellular substances are high molecular weight carbohydrate polymers intensively examined in molecular studies. Apart from structure, different EPS share the capacity for being used in biotechnology. The mean volume of periphyton bacteria that occurred on the surface of stones and algae was 0.2 and $0.29 \mu \mathrm{m}^{3}$, respectively. A high metabolic activity of cells was an important feature of the bacterioperiphyton (Fig. 5). Among the cells occurring on the surface of algae, those with an active cytoplasmic membrane (MEM+) represented about $40 \%$ of the overall number of bacteria, while cells with an active electron transport system (ETS), around 33\%.

Large shore zones flooded at high tides play a vital role in the functioning of the Ecology Lagoon ecosystem. In summer, autotrophic organisms (algae) and 
heterotrophic bacteria rapidly develop in these areas (Fig. 6). Occurrence of conglomerates of bacteria and algae is a very characteristic phenomenon. The conducted studies showed a very high rate of primary and secondary production. The intense metabolic activity of bacteria covering the surface of diatoms and filamentous algae is very symptomatic and indicates that auto- and heterotrophic microorganisms play the key role in the Ecology Lagoon ecosystem. The easily assimilated organic matter which is released by algae is a very good substrate for heterotrophic bacteria. The conglomerates of bacteria and algae are functioning as bioreactors. The biotransformation of the organic matter by bacteria causes formation of huge bacterial biomass used intensively by bacteria-feeding organisms. Algae and heterotrophic bacteria as well as flagellates and ciliates create a very effectively functioning trophic pathway.

The molecular studies showed considerable diversity in the taxonomic structure of the Ecology Lagoon bacteriocenosis. The PCR-DGGE analysis indicated the occurrence of 50 dominating taxa. About $30 \%$ of the isolated sequences were found in all the examined water and bacterioperiphyton samples. The remaining detected species-specific DNA sequences were unique to individual habitat types. The bacteria occupying stones made up a highly specific and taxonomically varied group of microorganisms. Species distribution in the individual samples of the bacterioperiphyton was very similar. In the water samples the number of dominating species was far lower. A statistically significant difference was shown in the taxonomic structure of the ocean water and the Ecology Lagoon water.

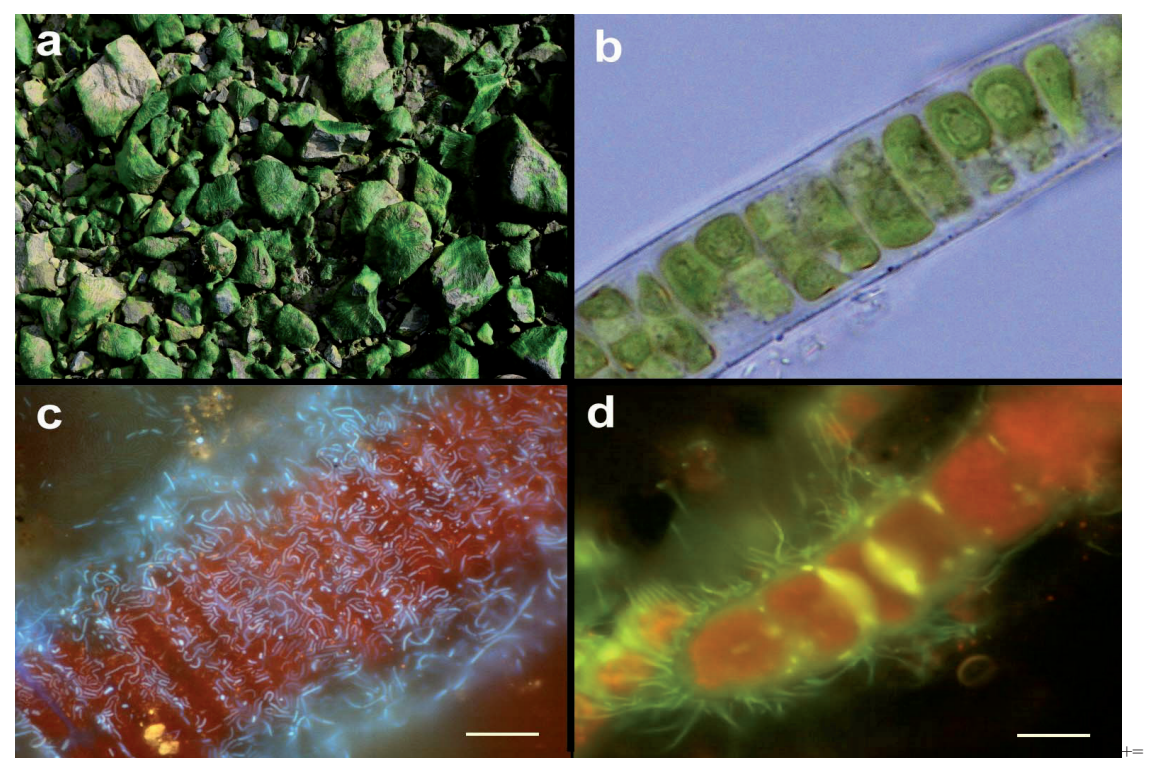

Figure 6. Filamentous algae on the stones surface ( $\mathrm{a}$ and $\mathrm{b}$ ), bacteria on the algae surface - DAPI staining (c), metabolic active bacteria (green) - BacLight ${ }^{\mathrm{TM}}$ staining (d), bar $-10 \mu \mathrm{m}$ 


\section{CONCLUSIONS}

Analyses of the obtained results suggests that the increase in the amount of organic matter and nutrients together with the high dynamics of physico-chemical parameters of the water in Ecology Lagoon affected the unique structure and functional characteristics of this ecosystem's biocenosis. The high metabolic activity of bacteria observed in the littoral zones of the lagoon determines the high intensity of processes such as microbiological decomposition, mineralisation and bioconversion of organic matter deposited in the reservoir. The above mentioned phenomena are of key importance in the stimulation and regulation of the rate at which the processes take place in the Ecology Lagoon ecosystem.

Acknowledgements. We thank Dr Julita Dunalska for her help in chemical analyses. The studies in the frame of CliCoPen ID No 34 have been supported by the Polish Ministry of Science and Higher Education as a special project No IPY/26/2007.

\section{REFERENCES}

Anisimov O.A., Belolutskaia M.A., 2004, Predictive modeling of climate change impacts on permafrost: effects of vegetation, Meteorol. Hydrol., 11, 73-81.

Bartosch S., Mansch R., Knötzsch K. Bock E., 2003, CTC staining and counting of actively respiring bacteria in natural stone using confocal laser scanning microscopy, Microbiol. Meth., 52, 75-84.

Birkenmajer K., 2002, Retread of Ecology Glacier, Admiralty Bay, King George Island (South Shetland Islands, West Antarctica), 1956-2001, Bull. Pol. Ac.: Earth Sci., 50, 15-30.

Boulos L., Prévost M., Barbeau B., Coallier J., Desjardins R., 1999, LIVE/DEAD ${ }^{\circledR}$ BacLight ${ }^{\mathrm{TM}}$ : application of a new rapid staining method for direct enumeration of viable and total bacteria in drinking water, Journal of Microbiological Methods, 37, 77-86.

Dickson B., 2009, Securing the legacy of the IPY, Nature Geoscience, 2, 374-376.

Grzesiak J., Żmuda-Baranowska M., Borsuk P., Zdanowski M., 2009, Microbial community at the front of Ecology Glacier (King George Island, Antarctica): Initial observations, Polish Pol. Res., 30, 37-47.

Janecki T., Kidawa A., Potocka M., 2010, The effects of temperature and salinity on vital biological functions of the Antarctic crustacean Serolis polita, Polar Biology, 33, 1013-1020.

Junge K., Eicken H., Deming J.W., 2004, Bacterial activity at -2 to $-20^{\circ} \mathrm{C}$ in Arctic wintertime sea ice, Applied and Environmental Microbiology, 70, 550-557.

López N.I., Ruiz J.A., Mendez B.S., 1998, Survival of poly3-hydroxybutyrate producing bacteria in soil microcosms, World J. Microbiol. Biotechnol., 14, 681-684.

Muyzer G., Dewaal E.C., Uitterlinden A.G., 1993, Profiling of complex microbial populations by denaturing gradient gel electrophoresis analysis of polymerase chain reaction amplified genes coding for 16S rRNA, Appl. Environ. Microbiol., 59, 695-700. 
Nędzarek A., Rakusa-Suszczewski S., 2004, Decomposition of macroalgae and the release of nutrient in Admiralty Bay, King George Island, Antarctica, Polar Bioscience, 17, 26-35.

Nyström T., 1995, The trials and tribulations of growth arrest, Trends Microbiol., 3, 131-136.

Poli A., Anzelmo G., Nicolaus B., 2010, Bacterial exopolysaccharides from extreme marine habitats: production, characterization and biological activities, Mar. Drugs, 8, 1779-1802.

Rakusa-Suszczewski S., 1995, Flow of matter in the Admiralty Bay area, King George Island, Maritime Antarctic, Proc. NIPR Symp. Polar Biol., 8, 101-113.

Rakusa-Suszczewski S., Zieliński K., 1993, 10, Macrophytobenthos, [in:] Rakusa-Suszczewski S., (ed.), The Maritime Coastal Ecosystem of Admiralty Bay, Department of Antarctic Biology, Polish Academy of Sciences, Warsaw, 57-60.

Rignot E.J., 1998, Fast Recession of a West Antarctic Glacier, Science, 281, 549-551.

Zdanowski M., Wegleński P., Golik P., Sasin J.M., Borsuk P., Żmuda M.J., Stankovic A., 2004, Bacterial diversity in Adelie penguin, Pygoscelis adeliae, guano: molecular and morpho-physiological approaches, FEMS Microbiology Ecology, 50, 163-173.

Zdanowski M., Żmuda M. J., Zwolska I., 2005, Bacterial role in the decomposition of marine-derived material (penguin guano) in the terriestrial maritime Antarctic, Soil Biology and Biochemistry, 37, 581-595.

Zieliński K., 1990, Bottom macroalgae of the Admiralty Bay (King. George Island, South Shetland Islands, Antarctica), Pol. Polar Res., 11, 95-131. 